\title{
Endothelial cells from human cerebral aneurysm and arteriovenous malformation release ET-1 in response to vessel rupture
}

\author{
ELISA BOSCOLO ${ }^{1}$, GIACOMO PAVESI $^{2}$, PAOLO ZAMPIERI ${ }^{2}$, MARIA TERESA CONCONI $^{3}$, \\ CHIARA CALORE ${ }^{3}$, RENATO SCIENZA ${ }^{2}$, PIER PAOLO PARNIGOTTO ${ }^{3}$ and MARCELLA FOLIN ${ }^{1}$ \\ ${ }^{1}$ Department of Biology, Via Ugo Bassi 58/B, University of Padua; \\ ${ }^{2}$ Department of Neurosurgery, Via Giustiniani 5, University Hospital of Padua; \\ ${ }^{3}$ Department of Pharmaceutical Sciences, Via Marzolo 5, University of Padua, 35131 Padua, Italy
}

Received April 17, 2006; Accepted June 1, 2006

\begin{abstract}
Cerebral aneurysms and arteriovenous malformations (AVM) are a common cause of stroke and cerebral hemorrage. Both are often discovered when they rupture, causing subarachnoid hemorrhage ( $\mathrm{SAH}$ ). SAH-induced vasospasm is mediated by enhanced vasoconstriction due to endothelin-1 (ET-1). We investigated whether endothelial cells (ECs) obtained from aneurysm and AVM express phenotypic and genotypic alterations contributing to the development of vasospasm after SAH. We isolated ECs from human AVM and aneurysm and then confirmed their EC origin by polymerase chain reaction and immunocytochemistry with endothelial markers. Experiments were also carried out with human cerebral microvascular and umbilical vein ECs (HCECs and HUVECs respectively) for comparison. We tested EC proliferation ability and microtubule formation in Matrigel at different cell passages. Five aneurysm (3 ruptured, 2 unruptured) and 3 AVM (2 ruptured, 1 unruptured) ECs were tested for ET-1 release in the culture medium. Aneurysm and AVM ECs expressed von Willebrand factor, Adrenomedullin, and exhibited a progressive reduction of proliferation and in vitro angiogenic ability after the $\mathrm{V}$ passage. Significantly higher levels of ET-1 have been detected in ECs from ruptured aneurysms and AVMs. We report the first successful isolation and characterization of primary EC lines from human cerebral vascular lesions. Augmented release of ET-1 is correlated with the rupture of the abnormal vessel confirming its role in vasospasm after SAH. Furthermore, ECs obtained from these vascular malformations can be used as an experimental model to study $\mathrm{SAH}$-induced vasoconstriction.
\end{abstract}

Correspondence to: Dr Marcella Folin, Department of Biology, 6th floor, Via Ugo Bassi 58/B, 35131 Padua, Italy

E-mail: marcella.folin@unipd.it

Key words: endothelin, vasospasm, aneurysm, arteriovenous malformation, endothelial cells

\section{Introduction}

Endothelin (ET), one of the most potent vasoconstrictors, was first isolated from porcine aortic endothelial cells in 1988. Four isoforms are known (ET-1, -2, -3 and -4) (1). ET-1 is a small peptide of 21 amino acids with a molecular weight of $2492 \mathrm{Da}$. Its transcription can be induced within minutes from a precursor peptide, prepro-endothelin-1, in several steps via Big endothelin to mature ET-1 (2). ET-1 is generated mainly in endothelial cells and neurons, but also in glial cells, choroid plexus cells, hypothalamus, and macrophages invading the brain under pathological conditions (3-7). In cerebral vasculature, ET-1 evokes a dose-dependent and extremely longlasting constrictive effect in vivo and in vitro (8-11) by acting on ET-A and ET-B receptors present on the surface of vascular smooth muscle cells and endothelial cells. Various stimuli can increase the synthesis of ET-1: thrombin, transforming growth factor (TGF)- $\beta$, angiotensin II (1), oxyhemoglobin $(12,13)$, and interleukin 1 (14). Increased plasma endothelin levels have been demonstrated in patients after subarachnoid hemorrhage $(\mathrm{SAH})(15)$, in patients undergoing nonruptured abdominal aortic aneurysm (AAA) repair with infrarenal $(16,17)$ and supraceliac aortic cross-clamping (18), as well as in one animal model of infrarenal aortic clamping and subsequent exsanguinations.

To date, however, there are no reports of the endothelin response in ECs from patients undergoing repair of ruptured or unruptured cerebral aneurysm and arteriovenous malformation (AVM), vascular anomalies that can lead to SAH.

We report here for the first time the successful isolation and growth in vitro of primary EC lines from excised human cerebrovascular lesions. Then, we investigated whether there was an increase of ET-1 released by EC lines from either ruptured or unruptured vascular anomalies.

\section{Materials and methods}

Patients findings. This study has been approved by the local ethics committee. Samples were derived from surgical specimens of aneurysmal dome, AVM nidus obtained from patients operated on for aneurysm clipping or AVM excision. Eight 
Table I. Patient and lesion characteristics.

\begin{tabular}{lccl}
\hline Sample & Age & Sex & \multicolumn{1}{c}{ Description } \\
\hline AN 2 & 38 & Female & Ruptured middle cerebral artery aneurysm \\
AVM 3 & 23 & Female & Ruptured arteriovenous malformation \\
AN 4 & 56 & Female & Unruptured internal carotid artery aneurysm \\
AN 5 & 71 & Male & Ruptured middle cerebral artery aneurysm \\
AN 7 & 33 & Female & Ruptured internal carotid artery aneurysm \\
AN 8 & 69 & Female & Unruptured anterior cerebral aneurysm \\
AVM 9 & 26 & Female & Unruptured arteriovenous malformation \\
AVM 11 & 37 & Female & Ruptured arteriovenous malformation \\
\hline
\end{tabular}

Table II. Oligonucleotide primers used for reverse transcription polymerase chain reaction.

\begin{tabular}{|c|c|c|c|}
\hline Gene & Primer & Length (bp) & Reference sequence \\
\hline Endothelin-1 & $\begin{array}{l}\text { F: aagacaaaccaggtcggaga } \\
\text { R: tggaggctatggcttcagac }\end{array}$ & 154 & XM_043856 \\
\hline Endothelin receptor-a & $\begin{array}{l}\text { F: tctccatctggatcctgtcc } \\
\text { R: atgaagagggaaccagcaaa }\end{array}$ & 350 & XM_003485 \\
\hline Endothelin receptor-b & $\begin{array}{l}\text { F: ccctgaagccataggttttg } \\
\text { R: cagagggcaaagacaaggac }\end{array}$ & 303 & XM_007108 \\
\hline Calcitonin receptor-like receptor & $\begin{array}{l}\text { F: agaaggcgtttactgcaacag } \\
\text { R: tccetgtccaattatggtcag }\end{array}$ & 271 & XM_043055 \\
\hline Glyceraldehyde-3-phosphate dehydrogenase & $\begin{array}{l}\text { F: tggggaaggtgaaggtcgga } \\
\text { R: gaggtcaatgaaggggtcat }\end{array}$ & 100 & ВC004109 \\
\hline Adrenomedullin & $\begin{array}{l}\text { F: acttcggagttttgccattgc } \\
\text { R: catccggactgctgtcttc }\end{array}$ & 358 & ВC015961 \\
\hline
\end{tabular}

F, forward; R, reverse.

specimens were collected (7 female, 1 male; age range 23-71 years). Ruptured aneurysms and AVMs were operated on within $48 \mathrm{~h}$ after hemorrhage. Normal brain microvasculature specimens were obtained from normal frontal lobe tissue of 2 males and 2 females. Table I gives a description of samples and summarizes the clinical characteristics.

Isolation and culture of endothelial cells from human brain vascolature, brain aneurysm and arteriovenous malformation. Tissue was sectioned into 3- $\mathrm{mm}^{2}$ fragments, washed with PBS, and incubated in $0.1 \%$ collagenase $\mathrm{B} / 0.1 \%$ dispase (Roche, Basel, Switzerland) at $37^{\circ} \mathrm{C}$ for $25 \mathrm{~min}$. In order to isolate ECs, the pre-digested tissue was triturated by a 2-ml pipette for $2 \mathrm{~min}$ and then filtered through a $100-\mu \mathrm{m}$ strainer (BD Biosciences, NJ, USA). Cell suspension was centrifuged and re-suspended in culture medium MV2 supplemented with growth factors and 20\% foetal bovine serum (FBS) (PromoCell, Heidelberg, Germany). Cells were then seeded at a density of 104 cells $/ \mathrm{cm}^{2}$ on fibronectin $\left(1 \mu \mathrm{g} / \mathrm{cm}^{2}\right)$ (Sigma Aldrich Inc.,
St. Louis, MO, USA)-coated dishes and grown for $24 \mathrm{~h}$ at $37^{\circ} \mathrm{C}$ with $5 \% \mathrm{CO}_{2}$. The day after seeding, cells were washed with PBS to remove unattached cells and fed with fresh medium. To obtain pure ECs, cultures grown to $80-100 \%$ confluence were exposed to immunoseparation using Ulex europaeus Agglutinin I (UEA)-coated (Vector Laboratories, Ltd., Peterborough, UK) beads (Dynabeads M-450 Tosylactivated, Oxoid, Hampshire, UK) as described by Jackson et al (19). ECs bound to the lectin-coated beads were collected with a magnetic particle concentrator and unbound cells were removed with 2 washes with basal medium. UEA-positive cells were re-suspended in culture medium and seeded on fibronectin-coated dishes to improve their adhesion and growth. Cultures became confluent within 4-6 days.

Characterization of endothelial cells. Immunocytochemistry to characterize the isolated cells was performed with rabbit polyclonal anti-human vWF (diluted 1/300; Dako Corp., Carpinteria, California, USA). For immunostaining, cells were 

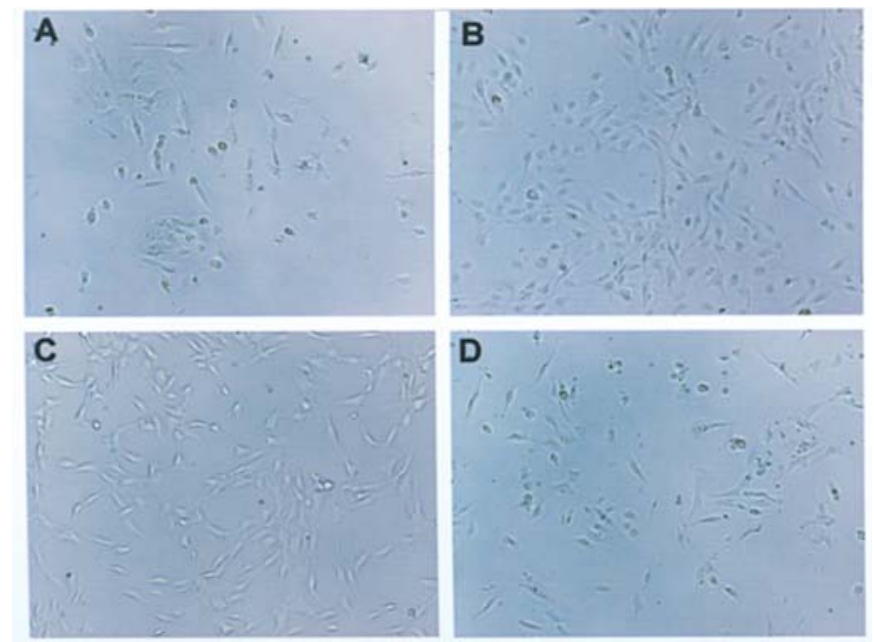

Figure 1. Endothelial cells isolated from different specimens. EC cultures established from human normal brain vascolature (A), cerebral aneurysm (C) and cerebral AVM (D) consist mostly of fusiform cells compared to HUVE cells (B). All the EC lines have been cultured under identical conditions, as revealed by phase-contrast microscopy. Magnification, x100.

grown in MV2 on fibronectin-coated chamber slides, washed in PBS, and fixed in ice-cold acetone for $10 \mathrm{~min}$ at $4^{\circ} \mathrm{C}$. Immunostaining was performed at room temperature and cells were washed 3 times in PBS after each step. PBS with $1 \%$ BSA was used for antibody dilution. Cells were treated with $1 \%$ Triton in PBS for $5 \mathrm{~min}$ at room temperature and then incubated at room temperature with $0.5 \%$ BSA in PBS for 15-20 min to block nonspecific binding sites. The primary antibody rabbit anti-human von Willebrand factor (1:300) was added, followed by secondary peroxidase-conjugated anti-rabbit immunoglobulin G (1:150) incubation. The reaction was developed with avidin-biotin amplified immunoperoxidase method using the Large Volume Dako LSAB Peroxidase kit (Dako, Glostrup, Denmark). Finally, nuclei were counterstained with hematoxylin. Negative controls were performed by similarly treating cultures and omitting the primary antibody.

Endothelial cell proliferation assay. ECs $\left(5 \times 10^{4}\right)$ at different passage numbers were re-suspended in MV2/20\% FBS, seeded in each well of 24-multiwell plates and incubated in a $5 \% \mathrm{CO}_{2}$ incubator at $37^{\circ} \mathrm{C}$ for $24 \mathrm{~h}$. Proliferation was measured after 1 wash in PBS and trypsinization. Cells were collected and counted using Trypan blue staining. Results are means of 4 experiments.

Cell proliferation was also measured after $24 \mathrm{~h}$ using BrdU incorporation (Cell Proliferation ELISA, BrdU, Roche Applied Science, Monza, Italy). Briefly, BrdU labeling solution was added to the medium and incubated in a $5 \% \mathrm{CO}_{2}$ incubator at $37^{\circ} \mathrm{C}$ for $18 \mathrm{~h}$. The culture medium was removed after the labeling step and the FixDenat (cell fixation and DNA denaturation) reagent was added. After 30-min incubation at room temperature, the FixDenat was removed. Subsequently, cells were incubated with anti-BrdU-POD antibody conjugate for $1 \mathrm{~h}$. Wells were then washed before substrate was added. The absorbance was determined at a 405-nm wavelength, with a reference wavelength of 490-nm, with a microplate autoreader EL 13. The results were means of 4 experiments.
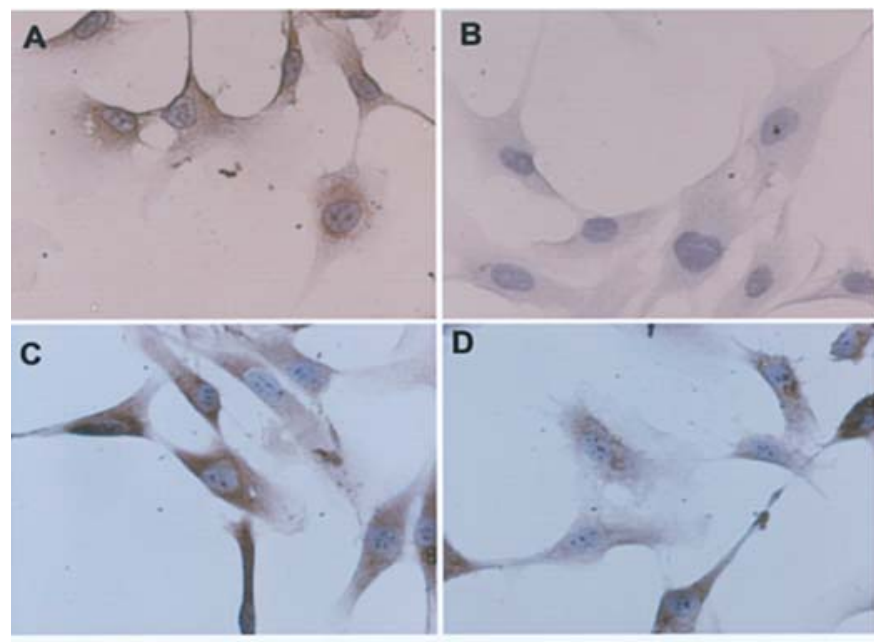

Figure 2. Immunocytochemical staining of endothelial cells. Purified HCECs stained positively for von Willebrand Factor (vWF) antibody showing a typical punctate brown (DAB) immunoreaction (A), which is not detectable if primary antibody is omitted (B). ECs from brain AVM and aneurysm also stained positively for $\mathrm{vWf}$ (C and $\mathrm{D}$ respectively). Nuclei are counter-stained with hematoxylin. Magnification, x10.

$P C R$. Total RNA was extracted from $5 \times 10^{6}$ cultured endothelial cells according to the Trizol method (Life Technologies, Carlsbad, CA, USA). mRNA was reverse-transcribed with the use of MultiScribe RT (Applied Biosystems, Foster City, CA, USA) and oligo-dT as primers for the first strand cDNA synthesis. The amplification of the resulting cDNA was carried out using specific primers (Table II). Briefly, in a thermal cycler (I-Cycler; Bio-Rad, Milan, Italy), after an initial denaturation step at $95^{\circ} \mathrm{C}$ for $10 \mathrm{~min}$, we used a denaturation step at $95^{\circ} \mathrm{C}$ for $30 \mathrm{sec}$, an annealing step at $60^{\circ} \mathrm{C}$ for $45 \mathrm{sec}$, and an extension step at $72^{\circ} \mathrm{C}$ for $45 \mathrm{sec}$ for a total of 35 cycles. To rule out the possibility of amplifying genomic DNA, RNA samples were treated with DNase (Ambion, Inc., Austin, TX, USA). Detection of the PCR amplification products was performed through electrophoresis on $2 \%$ agarose gel.

Capillary tube formation on Matrigel. We also checked purified control ECs, aneurysm and AVM ECs for their ability to form capillary-like structures at different passages. Briefly, growth factor reduced-Matrigel (BD Biosciences) was thawed on ice overnight and spread evenly over each well $(50 \mu \mathrm{l})$ of a 24-well plate. The plates were incubated for $30 \mathrm{~min}$ at $37^{\circ} \mathrm{C}$ to allow the Matrigel to gel. ECs $\left(2.5 \times 10^{2}\right.$ cells $\left./ \mathrm{mm}^{2}\right)$ were seeded into each well in $500 \mu \mathrm{l}$ of MV2/20\% FBS medium and incubated for $24 \mathrm{~h}$ at $37^{\circ} \mathrm{C}$. Cultures were fixed with $10 \%$ paraformaldehyde and photographed ( 5 fields per well) at a magnification of $x 5$. Phase contrast images were recorded using a digital camera (DG 200; Leica Imaging System, Cambridge, UK) connected to a Laborlux-S microscope. Image analysis was carried out using the Qwin image analysis software (Leica Imaging System), and the dimensional (percent area covered by cells and total length of cell network per field) and topological (mesh number and branching points per field) parameters were estimated. 

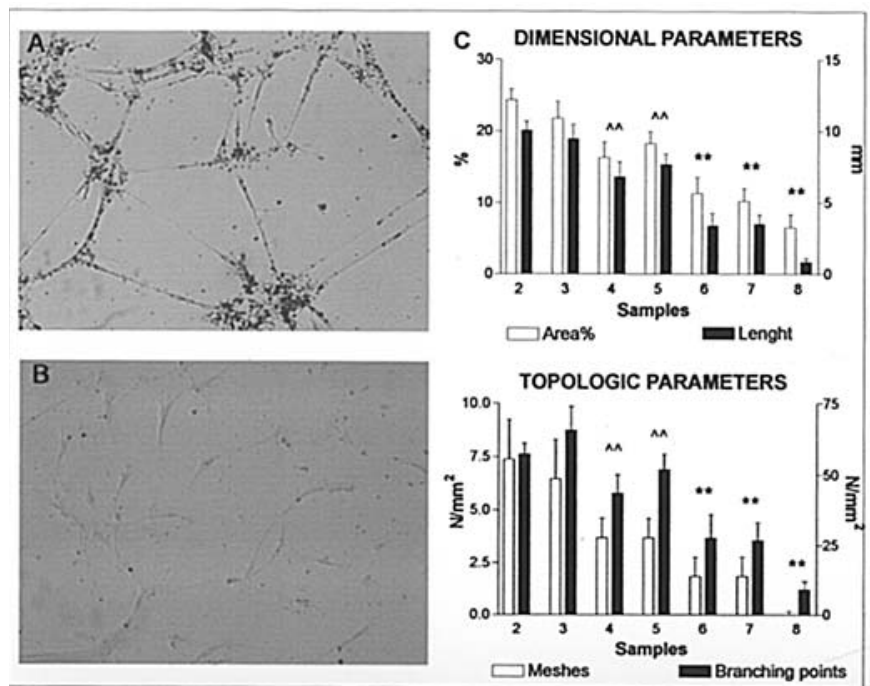

Figure 3. Tube formation by ECs on Matrigel. Representative photographs of HCECs at passage IX cultured on Matrigel after incubation for $24 \mathrm{~h}(\mathrm{~A})$, and ECs from aneurysm 2 at passage VIII (B). Original magnification, x5. Quantitative analysis of tube formation (C). Each column represents mean \pm S.D. of 5 different fields for each of 2 independent experiments carried out with aneurysm cells. Results are compared with every other passage. Statistical significance: ${ }^{* *} \mathrm{p}<0.05$ comparing results with passages II, III, IV, $\mathrm{V} ;{ }^{\wedge} \mathrm{p}<0.05$ comparing results with passage II. Statistical analysis was performed by ANOVA followed by Bonferroni test.

Measurement of ET-1. Purified ECs on II passage were seeded in MV2/20\% FBS at $10^{2}$ cells $/ \mathrm{mm}^{2}$ in $10^{3}-\mathrm{mm}^{2}$ plates and cultured. The medium was removed after $24 \mathrm{~h}$ and stored at $-80^{\circ} \mathrm{C}$ until assayed. Frozen samples were thawed on ice and centrifuged for $5 \mathrm{~min}$ at $1500 \mathrm{rpm}$ to remove any residual cell. The supernatant was then assayed for ET-1 by using the Endothelin-1 EIA kit (Cayman, Ann Arbor, MI, USA) that consists of a 96-well plate coated with a monoclonal antibody specific for endothelin. Experiments were run in triplicate. After adding the standards, controls, and samples, an Acetylcholinesterase: Fab' conjugate was added as the detection antibody to form a sandwich, and the plate was incubated overnight at $4^{\circ} \mathrm{C}$. After several washes, the wells were incubated with Ellman's reagent at room temperature until colour was detectable, the plate was read in a plate reader at $405-\mathrm{nm}$. The standard curve was plotted and the samples read off the curve, since the amount of colour developed is directly proportional to the amount of ET-1 immunoreactivity (IR) present in the sample. The assay is sensitive enough to detect $\geq 1.5 \mathrm{pg} / \mathrm{ml}$ of endothelin.

Statistical analysis. Values are presented as mean \pm S.D. Data within each group were compared by ANOVA for repeated measurements and, if significant, a post hoc comparison by Bonferroni test was performed. Significance was defined as $\mathrm{p}<0.05$. Statistical analysis was performed using Primer software.

\section{Results}

Characterization of isolated ECs. To verify that the isolated Ulex europaeus I bead-bound cells, shown in Fig. 1, were

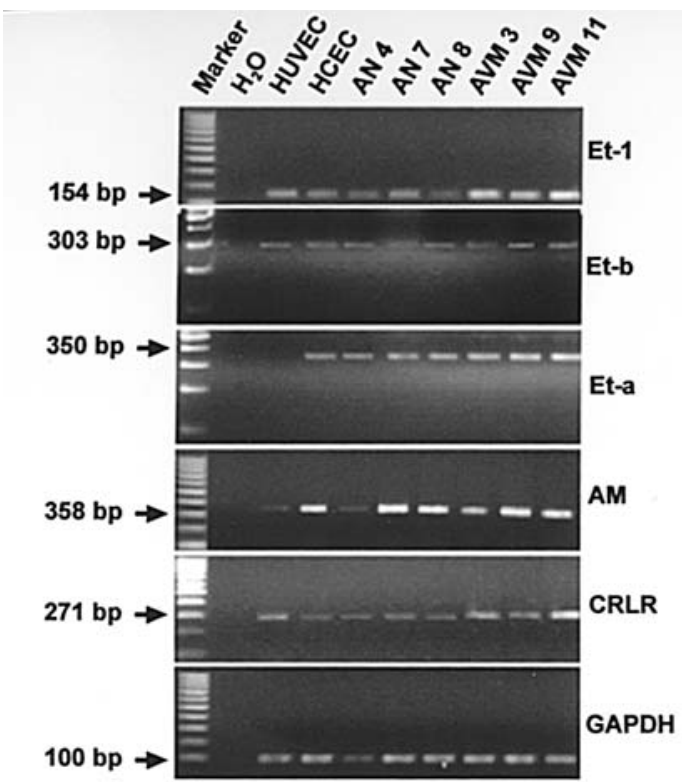

Figure 4. mRNA expression of EC markers. Agarose gel electrophoresis of different mRNA. Endothelin-1 (Et-1) and its receptors Endothelin-a (Et-a) and Endothelin-b (Et-b) have been detected in 3 out of 3 aneurysm (AN), and in 3 out of 3 arteriovenous malformation (AVM) ECs. Adrenomedullin (AM) and its receptor (CRLR) mRNAs have been detected in ECs from different brain vascular anomalies and for comparison in HCECs and in HUVECs. Bands are normalized with glyceraldehyde-3-phosphate dehydrogenase (GAPDH).

indeed endothelial and free from contaminating non-ECs, we analyzed expression of endothelial-specific marker vWF by immunocytochemistry. ECs exhibited punctate cytoplasmic staining with anti-vWF (Fig. 2A), consistent with localization of $\mathrm{vWF}$ in Weibel-Palade bodies, a definitive feature of ECs. No background staining was observed omitting the primary antibody (Fig. 2B). Some smooth muscle $\alpha$-actin (1-2\%) positive cells were seen from passage $\mathrm{V}$, with detectable increase by increased passage number (data not shown). In our experiments we used cells at passage II that stained $95 \%$ positive for vWF.

AM expression. ECs that we isolated had been analyzed for the expression of Adrenomedullin (AM) and its receptor Calcitonin receptor-like receptor (CRLR). AM was established as an important secretory product of vascular endothelium, together with nitric oxide, endothelins and prostanoids $(20,21)$. In our results gel electrophoresis showed that $\mathrm{AM}$ and its receptor CRLR mRNAs are expressed in ECs isolated from both cerebral vascular malformations, at the same level as in HCECs (Fig. 4).

Endothelial cell growth and microtubule network formation. Cell proliferation assay, developed by counting the cells, has shown that the number of the cells collected after $24 \mathrm{~h}$ increased slightly from the II-V generation. From the V passage the number of cells collected decreased. Cell growth conditions were the same for all experiments. Immunologic assay, based on BrdU incorporation, confirmed these results showing a bell-shaped curve for proliferation at different passage numbers. We obtained these results with endothelial 


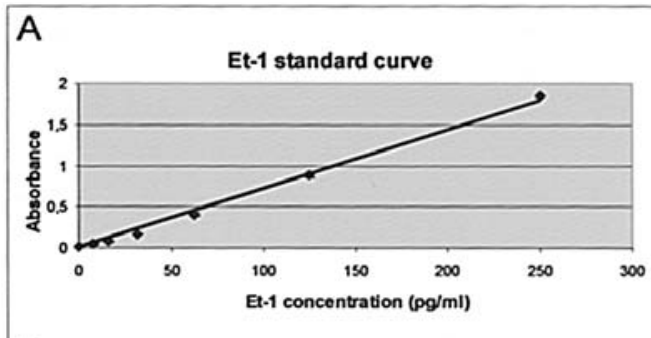

B
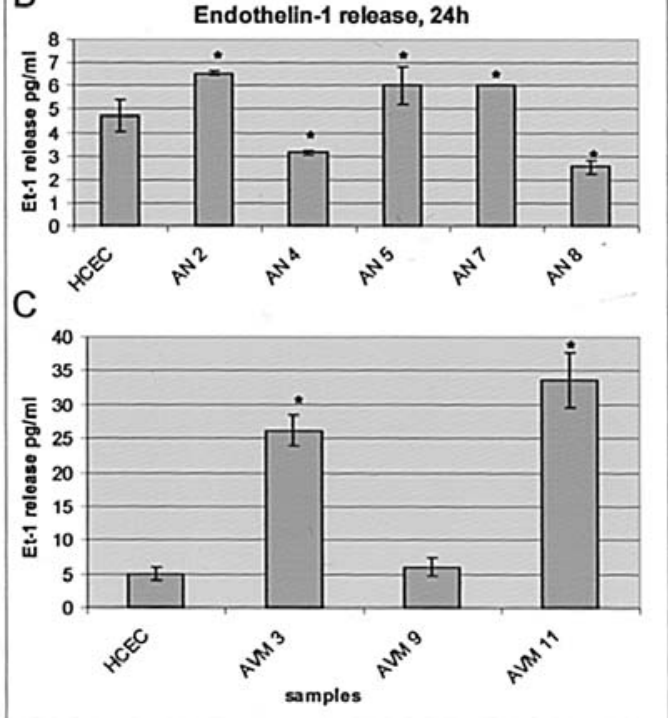

Figure 5. Endothelin-1 release. Representative standard curve for Et-1 (A) which has been used to plot absorbance for the samples in B. Et-1 concentration level in the medium of ECs from aneurysm (AN) and from brain microvasculature (HCECs). (C) The graph shows Et-1 release after $24 \mathrm{~h}$ from arteriovenous malformation ECs (AVM) and HCECs as control, standard curve for this experiment has not been shown. Error bars represent S.D. ( $n=3$ experiments). Each group has been compared with control values (HCECs), ${ }^{*} \mathrm{p}<0.05$ versus control. Statistical analysis was performed by ANOVA followed by Bonferroni test.

cells from every kind of vascular malformation analyzed. The proliferation ability of HCECs and HUVEC did not present any significant variation at different passage numbers until passage XII (data not shown).

To determine whether ECs from brain vascular malformation retain angiogenic potential, we also examined an in vitro angiogenesis model. Capillary-like tube formation was assessed in ECs from aneurysm, AVM and from normal brain microvascolature on growth factor-reduced Matrigel (22). Cells were seeded onto a Matrigel thin layer and, after $24 \mathrm{~h}$, the formation of capillary-like structures was evaluated. Control cells, HCECs until IX passage showed a great ability to form capillary structures. After quantification, we did not detect any significant changes in microtubule network formation ability between different passages analyzed, from II-IX (data not shown). Fig. 3A shows a picture of HCECs at passage IX seeded in Matrigel after $24 \mathrm{~h}$. For comparison, ECs from aneurysm 4 at passage VIII after $24 \mathrm{~h}$ are shown in Fig. 3B. Capillary-formation ability of ECs from aneurysms and AVM exhibited a slow decrease correlated with the increase of cell passage. Quantitative results indicate that ECs from vascular anomalies studied retain angiogenic ability from the II-V passage (Fig. 3C). Significant decrease of angiogenic properties has been detected from passage VI $(\mathrm{p}<0.05)$. Angiogenic ability almost disappeared from the VIII cell passage as confirmed with analysis of parametric and topologic parameters.

Endothelin-1. Several authors have demonstrated increase of Et-1 concentration in plasma and cerebral spinal fluid (CSF) after subarachnoid hemorrhage. Our interest was to determine if endothelial cells from cerebral vascular anomalies as aneurysm and AVM showed an increase of the basal release of ET-1. A total of 8 patients were examined, 5 aneurysm and 3 AVM. Endothelial cells were cultured and after $24 \mathrm{~h}$ the medium was collected and subjected to ET-1 measurement. In aneurysm ECs and HCECs ET-1 release is in the range of 2.5-6.9 pg/ml. Results obtained showed, compared to control, a significant increase $(\mathrm{p}<0.05)$ of ET-1 release in ECs from ruptured aneurysms and a significant decrease $(\mathrm{p}<0.05)$ in unruptured aneurysms (Fig. 5B). We found the same correlation between ET-1 release and brain vascular anomaly rupture in ECs isolated from AVM (Fig. 5C). Media collected from ruptured AVM ECs showed a significant increase $(p<0.05)$ in ET-1 concentration compared to HCECs (approximately 4-7 fold higher). Furthermore AVM 9, which is unruptured, showed ET-1 concentration levels comparable to HCECs. Et-1 expression has also been detected by PCR (Fig. 4). Comparing Et-1 gel bands with Glyceraldehyde-3-phosphate dehydrogenase (GAPDH) we can confirm that ECs that release high levels of ET-1 also have high Et-1 mRNA concentration, suggesting that the increase of ET-1 is also at the transcriptional level. Furthermore, ECs from cerebral vessels show expression of both ET-1 receptor mRNAs, Et-a and Et-b $(23,24)$, whereas HUVECs express only Et-b (Fig. 4).

\section{Discussion}

Reports about culturing of endothelial cells (ECs) from human intracranial vascular malformations are scarce. We describe for the first time a simple protocol for the isolation and growth in vitro of human cerebral aneurysm and arteriovenous malformation ECs. We obtained successful characterization of these ECs by means of such typical endothelial markers as von Willebrand factor, Adrenomedullin (AM) and Calcitonin receptor-like receptor (CRLR). We found that until passage $\mathrm{V}$ cerebral malformation ECs possess a good proliferation rate and tube formation abilty in Matrigel.

Intracranial aneurysms usually develop at the bifurcation of the conductive cerebral arteries in the subarachnoid space at the base of the brain $(25,26)$. An inherited maldevelopment of the supportive structure of cerebral arterial walls with a lack or disruption of the internal elastic lamina, (25-29) together with hemodynamic stress (30), may facilitate formation of aneurysms. A rupture of an aneurysm causes subarachnoid bleeding or hemorrhage (SAH).

AVMs are high-flow lesions consisting of arteries and veins with direct fistulous communications and lacking normal intervening capillary beds (31). The molecular mechanism inherent to the genesis and maintenance of these abnormal vascular phenotypes has not been elucidated. The most morbid and frequent presentation of AVMs is cerebral hemorrhage (32) and less frequently can lead to hemorrhage in the subarachnoid space (SAH) (33-35). 
SAH is a serious neurosurgical emergency generally associated with a consistent morbidity and mortality due to vasospasm (36). SAH-induced vasospasm can affect nearly $30 \%$ of patients, leading to further delayed ischemic consequences. For this reason many studies have attempted to identify the risk factors contributing to aneurysm and AVM formation and rupture and to investigate the pathogenesis of $\mathrm{SAH}$-induced vasospasm.

ET-1 is a potent vasoconstrictor that has been studied extensively as a mediator of vasospasm (37-42). The evidence that ET-1 is important in the vasoconstriction seen in SAHinduced vasospasm is based on 3 findings: i) levels of ET-1 are increased in CSF and plasma of patients with vasospam (43); ii) experimental vasospasm can be evoked by administration of ET-1; and iii) antagonists of ET-1 attenuate the vasoconstriction in experimental vasospasm (44).

In isolated canine mammary veins and in cultured bovine arterial cells, oxyhemoglobin caused a significant increase of ET-1 in the incubation medium. Methemoglobin also increased ET-1 levels $(45,13)$. The effect of oxyhemoglobin on the stimulation of ET-1 production was much higher than that induced by other stimulators, such as thrombin and phorbol-12-myrisate-13-acetate. Therefore, it is suggested that the oxyhemoglobin-induced ET-1 production in endothelial and smooth muscle cells is regulated by protein kinase $\mathrm{C}$ and a cyclic adenosine monophosphate-dependent pathway. Cisternal administration of ET-1 caused a delayed and prolonged spasm of intracranial vasculature in animal models $(9,10,39)$ and isolated cerebral vessels reacted with a strong and long-lasting vasoconstriction after ET-1 exposure from the adventitial side (46).

Our observations have shown increased ET-1 release in vitro from ECs of ruptured aneurysm and AVM. We propose the following pathophysiological sequence: The blood clot formed after the vessel rupture releases oxyhemoglobin $(\mathrm{OxyHb})$ in increasing concentrations into the subarachnoid space. OxyHb, interacting with the abluminal side of the endothelium, enhances the release of ET-1 and its vasoconstrictive effect $(9,12)$.

In contrast, Pluta and colleagues did not support the hypothesis that ET-1 formation is stimulated by $\mathrm{OxyHb}(47)$. An in vitro examination has demonstrated that ET-1 formation in cultured endothelial cells did not increase $6 \mathrm{~h}$ after exposure to hemoglobin, whereas the production of ET-1 was significantly elevated in cultured astrocytes. In a primate model of SAH there was no correlation between the development of vasospasm and the perivascular ET-1 levels. Some authors have suggested that ET-1 in CSF is unlikely to be derived only from the systemic vasculature and have postulated that ET-1 is released by mononuclear leucocytes in the CSF stimulated by aging blood $(48,49)$. Another study has shown that the ppET-1 gene is locally repressed in AVM lesions (50).

We show that ECs obtained from ruptured aneurysms and AVMs participate in ET-1 release following SAH. However, we cannot yet demonstrate if $\mathrm{OxyHb}$ is responsible for this. Some authors suggest that $\mathrm{OxyHb}$ by itself is insufficient to elicit the degree of vasoconstriction that they observed with the whole hemolysate (51). Kastner et al showed that only ET-1 levels in cerebrospinal fluid (CSF) correlate with cerebral vasospasm after SAH and not ET-1 levels in plasma (43). In accordance with these findings we demonstrate here that ET-1 release is a localized event that follows vessel rupture and hemorrhage. Further studies are needed in order to clarify if injured ECs are solely responsible for the ET-1 augmented release observed by some authors in patient plasma (52) and by other authors in CSF (43), or if other cells participate in this process. We suggest using damaged ECs from aneurysm and AVM as an experimental model to elucidate ET-1 receptor antagonist actions $(53,54)$ on human cells that have already been subjected to in vivo mechanical stresses and hemorrhage induction.

In summary, we report here for the first time the successful isolation and growth in vitro of primary EC lines from excised human cerebral aneurysm and AVM. We show that augmented release of ET-1 is correlated with the rupture of the abnormal vessel suggesting a specific role of ECs during vasoconstriction. As ECs grown in vitro maintain, after a few passages, the in vivo ability to release ET-1, we suggest that these cells should be used as an experimental model to study SAH-induced vasoconstriction.

\section{Acknowledgements}

This work was supported by a grant from Veneto Region (Ricerca Sanitaria Finalizzata 62/02). We thank Diego Giudolin for his helpful support during the use of Qwin image analysis software.

\section{References}

1. Yanagisawa $\mathrm{M}$ and Masaki T: Molecular biology and biochemistry of the endothelins. Trends Pharmacol Sci 10: 374-378, 1989.

2. Schmidt M, Kroger B, Jacob E, Seulberger H, Subkowski T, Otter R, Meyer T, Schmalzing G and Hillen H: Molecular characterization of human and bovine endothelin converting enzyme (ECE-1). FEBS Lett 356: 238-243, 1994

3. Ehrenreich H, Anderson RW, Fox CH, Rieckmann P, Hoffman GS, Travis WD, Coligan JE, Kehrl JH and Fauci AS: Endothelins, peptides with potent vasoactive properties, are produced by human macrophages. J Exp Med 172: 1741-1748, 1990.

4. Ehrenreich H, Kehrl JH, Anderson W, Rieckmann P, Vitkovic L, Coligan JE and Fauci AS: A vasoactive peptide, endothelin-3, is produced by and specifically binds to primary astrocytes. Brain Res 538: 54-58, 1991

5. Giaid A, Gibson SJ, Ibrahim NBN, Legon S, Bloom SR, Yanagisawa M, Masaki T, Varndell IM and Polak JM: Endothelin-1, an endothelium-derived peptide, is expressed in neurons of the human spinal cord and the dorsal root ganglia. Proc Natl Acad Sci USA 86: 7634-7638, 1989.

6. MacCumber MW, Ross CA and Snyder SH: Endothelin in brain: Receptors, mitogenesis, and biosynthesis in glial cells. Proc Natl Acad Sci USA 87: 2359-2363, 1990.

7. Yoshizawa T, Shimni O, Giaid A, Yanagisawa M, Gibson SJ, Kimura S, Uchiyama Y, Polak JM, Masaki T and Kanazawa I: Endothelin: A novel peptide in the posterior pituitary system. Science 247: 462-464, 1990.

8. De Nucci G, Thomas R, D'Orleans-Juste P, Antunes E, Walder C, Warner TD and Vane JR: Pressor effects of circulating endothelin are limited by its removal in the pulmonary circulation and by the release of prostacyclin and endothelium-derived relaxing factor. Proc Natl Acad Sci USA 85: 9797-9800, 1988.

9. Kobayashi H, Hayashi M, Kobayashi S, Kabuto M, Handa Y and Kawano H: Effect of endothelin on the canine basilar artery. Neurosurgery 27: 357-361, 1990.

10. Mima T, Yanagisawa M, Shigeno T, Saito A, Goto K, Takakura K and Masaki T: Endothelin acts in feline and canine cerebral arteries from the adventitial side. Stroke 20: 1553-1556, 1989. 
11. Papadopoulos S, Gilbert L, Webb C and Amato C: Characterization of contractile responses to endothelin in human cerebral arteries: Implications for cerebral vasospasm. Neurosurgery 26: 810-815, 1990.

12. Ohlstein EH and Storer BL: Oxyhemoglobin stimulation of endothelin production in cultured endothelial cells. J Neurosurg 77: 274-278, 1992.

13. Kasuya H, Weir BKA, White DM and Stefanson K: Mechanism of oxyhemoglobin-induced release of endothelin-1 from cultured vascular endothelial cells and smooth muscle cells. J Neurosurg 79: 892-898, 1993.

14. Yoshizumi M, Takaku F, Yanagisawa M, Masaki T and Yazaki Y: Interleukin 1 increases the production of endothelin- 1 by cultured endothelial cells. Biochem Biophys Res Commun 166: 324-329, 1990.

15. Suzuki R, Masaoka H, Hirata Y, Marumo F, Isotani E and Hirakawa K: The role of endothelin-1 in the origin of cerebral vasospasm in patients with aneurysmal subarachnoid hemorrhage. J Neurosurg 77: 96-100, 1992.

16. Antonucci F, Bertolissi M and Calo L: Plasma endothelin and renal function during infrarenal aortic crossclamping and nifedipine infusion. Lancet 336: 1449, 1990.

17. Fukuda S, Taga K, Tanaka T, Sakuma K, Fujiwara N, Shimoji K and Fujihara H: Relationship between tissue ischemia and venous endothelin-1 during abdominal aortic aneurysm surgery. J Cardiothorac Vasc Anesth 5: 510-514, 1995.

18. Lintott P, Hafez HM and Stansby G: Spinal cord complications of thoracoabdominal aneurysm surgery. Br J Surg 85: 5-15, 1998.

19. Jackson CJ, Garbett PK, Nissen B and Schrieber L: Binding of human endothelium to Ulex europaeus I-coated Dynabeads: application to the isolation of microvascular endothelium. J Cell Sci 96: 257-262, 1990.

20. Kitamura K, Kangawa K, Kawamoto M, Ichiki Y, Nakamura S, Matsuo $\mathrm{H}$ and Eto T: Adrenomedullin: a novel hypotensive peptide isolated from human pheochromocytoma. Biochem Biophys Res Commun 192: 553-560, 1993.

21. Sugo S, Minamino N, Kangawa K, Miyamoto K, Kitamura K, Sakata J, Eto T and Matsuo H: Endothelial cells actively synthesize and secrete adrenomedullin. Biochem Biophys Res Commun 201: 1160-1166, 1994.

22. Donovan D, Brown NJ, Bishop ET and Lewis CE: Comparison of three in vitro human angiogenesis assays with capillaries formed in vivo. Angiogenesis 4: 113-121, 2001.

23. Rubanyi GM and Polokoff MA: Endothelins: Molecular biology, biochemistry, pharmacology, physiology, and pathophysiology. Pharmacol Rev 46: 325-415, 1994.

24. Chen Y, McCarron RM, Golech S, Bembry J, Ford B, Lenz FA, Azzam N and Spatz M: ET-1- and NO-mediated signal transduction pathway in human brain capillary endothelial cells. Am J Physiol Cell Physiol 284: 243-249, 2003.

25. Gao YZ, van Alphen $\mathrm{H}$ and Kamphorst W: Observations on experimental saccular aneurysms in the rat after 2 and 3 months. Neurol Res 12: 260-263, 1990.

26. Yong-Zhong G and van Alphen HA: Pathogenesis and histopathology of saccular aneurysms: review of the literature. Neurol Res 12: 249-255, 1999.

27. Scanarini M, Mingrino S, Giordano R and Baroni A: Histological and ultrastructural study of intracranial saccular aneurysmal wall. Acta Neurochir 43: 171-182, 1978.

28. van Donselaar CA, Stefanko SZ, van der Kwast TH, Arts WF and Koudstaal PJ: Basilar artery giant fusiform aneurysms caused by congenital defect of the internal elastic lamina and media. Clin Neuropathol 7: 68-72, 1988.

29. Kim C and Cervos-Navarro J: Spontaneous saccular cerebral aneurysm in a rat. Acta Neurochir 109: 63-65, 1991.

30. Turner CL, Tebbs S, Smielewski P and Kirkpatrick PJ: The influence of hemodynamic stress factors on intracranial aneurysm formation. J Neurosurg 95: 764-770, 2001.

31. Uranishi R, Baev NI, Ng PY, Kim JH and Awad IA: Expression of endothelial cell angiogenesis receptors in human cerebrovascular malformations. Neurosurgery 48: 359-367, 2001.

32. Hashimoto T, Emala CW, Joshi S, Mesa-Tejada R, Quick CM, Feng L, Libow A, Marchuk DA and Young WL: Abnormal pattern of Tie-2 and vascular endothelial growth factor receptor expression in human cerebral arteriovenous malformations. Neurosurgery 47: 910-918, 2000.

33. Matsumori K, Asahi S, Nakayama K, Miyasaka Y and Beppu T: Cerebral vasospasm following subarachnoid hemorrhage in arteriovenous malformation. No Shinkei Geka 11: 829-834, 1983.
34. Turjman F, Mimon S and Yilmaz H: Epidemiology, clinical study and pathology of vasospasm. J Neuroradiol 26: 10-16, 1999.

35. Clinchot DM, Kaplan P, Murray DM and Pease WS: Cerebral aneurysms and arteriovenous malformations: implications for rehabilitation. Arch Phys Med Rehabil 75: 1342-1351, 1994.

36. Kassell NF, Peerless SJ, Durward QJ, Beck DW, Drake CG and Adams HP: Treatment of ischemic deficits from vasospasm with intravascular volume expansion and induced arterial hypertension. Neurosurgery 11: 337-343, 1982.

37. Fujimori A, Yanagisawa M, Saito A, Goto K, Masaki T, Mima T, Takakura $\mathrm{K}$ and Shigeno T: Endothelin in plasma and cerebrospinal fluid of patients with subarachnoid haemorrhage. Lancet 336: 633, 1990.

38. Sasaki T and Kassell NF: The role of endothelium in cerebral vasospasm. Neurosurg Clin N Am 1: 451-463, 1990.

39. Kobayashi H, Hayashi M, Kobayashi S, Kabuto M, Handa Y, Kawano $\mathrm{H}$ and Ide $\mathrm{H}$ : Cerebral vasospasm and vasoconstriction caused by endothelin. Neurosurgery 28: 673-678, 1991.

40. Yamaura I, Tani E, Maeda Y, Minami N and Shindo H: Endothelin-1 of canine basilar artery in vasospasm. J Neurosurg 76: 99-105, 1992.

41. Gaetani P, Rodriguez y Baena R, Grignani G, Spanu G, Pacchiarini L and Paoletti P: Endothelin and aneurysmal subarachnoid haemorrhage: a study of subarachnoid cisternal cerebrospinal fluid. J Neurol Neurosurg Psychiatry 57: 66-72, 1994.

42. Seifert V, Loffler BM, Zimmermann M, Roux S and Stolke D: Endothelin concentrations in patients with aneurysmal subarachnoid hemorrhage. Correlation with cerebral vasospasm, delayed ischemic neurological deficits, and volume of hematoma. J Neurosurg 82: 55-62, 1995.

43. Kastner S, Oertel MF, Scharbrodt W, Krause M, Boker DK and Deinsberger W: Endothelin-1 in plasma, cisternal CSF and microdialysate following aneurysmal SAH. Acta Neurochir 147: 1271-1279, 2005.

44. Provencio JJ and Vora N: Subarachnoid hemorrhage and inflammation: bench to bedside and back. Semin Neurol 25: 435-444, 2005.

45. Cocks T, Malta E, King S, Woods R and Angus J: Oxyhaemoglobin increases the production of endothelin-1 by endothelial cells in culture. Eur J Pharmacol 196: 177-182, 1991.

46. Ceviker N, Baykaner MK, Keskil IS, Sencer H, Ataoglu O, Ozsoy $\mathrm{M}$ and Ercan ZS: Immediate ultrastructural effects of endothelin-1 on rabbit basilar artery. A comparison between immersion and perfusion fixation techniques. Acta Neurochir 132: 104-109, 1995

47. Pluta RM, Boock RJ, Afshar JK, Clouse K, Bacic M, Ehrenreich $\mathrm{H}$ and Oldfield EH: Source and cause of endothelin1 release into cerebrospinal fluid after subarachnoid hemorrhage. J Neurosurg 87: 287-293, 1997.

48. Bertsch T, Kuehl S, Muehlhauser F, Walter S, Hodapp B, Rossol S, Schmeck J, Ragoschke A, Schutt S, Fritzinger M, Horn P, Vajkoczy P, Wellner MW and Fassbender K: Source of endothelin-1 in subarachnoid hemorrhage. Clin Chem Lab Med 39: 341-345, 2001.

49. Fassbender K, Hodapp B, Rossol S, Bertsch T, Schmeck J, Schutt S, Fritzinger M, Horn P, Vajkoczy P, Wendel-Wellner M, Ragoschke A, Kuehl S, Brunner J, Schurer L, Schmiedeck P and Hennerici M: Endothelin-1 in subarachnoid hemorrhage: an acute-phase reactant produced by cerebrospinal fluid leukocytes. Stroke 31: 2971-2975, 2000.

50. Rhoten RL, Comair YG, Shedid D, Chyatte D and Simonson MS: Specific repression of the preproendothelin-1 gene in intracranial arteriovenous malformations. J Neurosurg 86: 101-108, 1997.

51. Chang CZ, Winardi D, Lin CL, Kwan AL, Jeng AY, Kassell NF, Howng SL and Lee KS: Attenuation of hemolysate-induced cerebrovascular endothelial cell injury and of production of endothelin-1 and big endothelin-1 by an endothelin-converting enzyme inhibitor. Surg Neurol 58: 181-187, 2002.

52. Secades JJ, Rubio E, Castellanos JM, de la Rosa MD, Mercadal J, Vilalta J, Catalan R and Galard RM: Subarachnoid hemorrhage, cerebral ischemia and endothelin-1. Rev Neurol. 30: 27-34, 2000.

53. Zuccarello M, Boccaletti R, Romano A and Rapoport RM: Endothelin B receptor antagonists attenuate subarachnoid hemorrhage-induced cerebral vasospasm. Stroke 9: 1924-1929, 1998.

54. Zuccarello M, Soattin GB, Lewis AI, Breu V, Hallak H and Rapoport RM: Prevention of subarachnoid hemorrhage-induced cerebral vasospasm by oral administration of endothelin receptor antagonists. J Neurosurg 84: 503-507, 1996. 